\title{
Possible Effects of Economic Public Policies Implemented in Brazil after the Financial Crisis of 2008 on Foreign Direct Investment
}

\author{
Maurício Loboda Fronzaglia, Álvaro Alves de Moura Júnior, Joaquim Carlos Racy, \\ Pedro Raffy Vartanian
}

Mackenzie Presbyterian University, São Paulo, Brazil

Email: mauricio.fronzaglia@ma ckenzie.br, alvaro.moura@mackenzie.br, racjo@uol.com.br, pedro.vartanian@mackenzie.br

How to cite this paper: Fronzaglia, M.L., de Moura Jr., A.A., Racy, J.C. and Vartanian, P.R. (2019) Possible Effects of Economic Public Policies Implemented in Brazil after the Financial Crisis of 2008 on Foreign Direct Investment. Theoretical Economics Letters, 9, 2800-2823. https://doi.org/10.4236/tel.2019.98176

Received: October 9, 2019

Accepted: December 6, 2019

Published: December 9, 2019

Copyright $\odot 2019$ by author(s) and Scientific Research Publishing Inc. This work is licensed under the Creative Commons Attribution International License (CC BY 4.0).

http://creativecommons.org/licenses/by/4.0/

\begin{abstract}
The objective of this article is to evaluate the effects of public economic policies, implemented in response to the economic crisis of 2008, on the flows of foreign direct investment in Brazil. It demonstrates, through the political sociology of public action, that the crisis generated a change in the references of Brazilian economic policies: from the policies of the so-called "macroeconomic tripod" to policies of the new economic matrix. The implementation of this change is expressed in multiple government actions, including the use of the National Bank for Economic and Social Development, to stimulate the internationalization of Brazilian companies. It seeks to identify the possible effects of public action through data on the evolution of direct foreign investment and the use of the Grubel-Lloyd index.
\end{abstract}

\section{Keywords}

Financial Crisis, Public Policy, Brazil, Foreign Direct Investment

\section{Introduction}

The objective of this research is to evaluate the impacts of the Brazilian public economic policies implemented in response to the 2008 crisis on foreign direct investment (FDI) inflows and outflows. In order to achieve the objective of this research, a characterization of the economic policy as public policy will be made, firstly by analyzing it according to the political sociology of the public action approach in its three key elements: the sector-global relationship, and the referential and dynamic interaction of actors. Subsequently, foreign direct investment will be described and defined along with its evolution (from the year 2000) 
and its importance to the Brazilian economy. Changes in public policies after the crisis will also be described. Finally, the impact of these policies on direct investment flows will be analyzed.

This research may contribute to the debate on the changes in public economic policies aimed at countering the effects of the 2008 international crisis. Specifically, in Brazil, we proceeded to a new assessment of their impacts, relating the changes in the president Dilma's macroeconomic policy and its relationship with foreign direct investment flows.

The economic policies adopted in response to the 2008 crisis will be analyzed through the political sociology of public action. These actions will be interpreted through their relations with other areas of government (the sectoral-global relationship), their reference as public policy (the legal, institutional and cultural parameters that form the referential), and the description of the actors and their interaction dynamics in the conception and implementation of the public policies considered here. In Brazil, there was a clear change in economic policy after the 2008 crisis, with effects on direct investment: The "macroeconomic tripod" was replaced by the so-called "New Economic Matrix." This is a major public policy paradigm opportunity (or a referential opportunity) whose consequences have not yet been sufficiently measured.

In this scenario, the state should assume a more interventionist and protectionist role, not only reducing the real interest rate, but also expanding subsidized credit and devaluing the exchange rate, among other actions. This change has impacted both FDI flows and outflows, which will be duly identified through the application of the Grubel-Lloyd index adapted, according to Grubel and Lloyd [1], with input data from foreign investment $\left(\mathrm{FDI}_{\text {in }}\right)$ and local investment in the foreign country (FDI ${ }_{\text {out }}$ ) obtained at UNCTAD [2].

We divided the article into five sections, the first being this introduction. Following is a review of the literature on public economic policy. The third section provides a brief overview of the 2008 financial crisis and analysis of economic policies in Brazil between 1999 and 2008, to assess the transition from the macroeconomic tripod to the new economic matrix. The fourth section evaluates the results of FDI input and output streams. Finally, the fifth section presents the conclusions of the paper, as well as crisis implications on FDI flows in Brazil.

\section{Literature Review: Economic Public Policies}

The economic crisis triggered at the end of 2007 determined a change in the conduct of public policies in Brazil. The reactions of the then President Luiz Inácio Lula da Silva's government to mitigate the possible effects of the crisis, intensified in the government of his successor Dilma Rousseff, were expressed in a paradigm shift of public economic policy: from the macroeconomic tripod to the New Economic Matrix. It was a profound change and entailed a series of actions that made up the crisis of the Brazilian economy. We intend to proceed with an analysis of this change of economic policy using three complementary 
approaches: the political sociology of public action, the theory of the "three Is" institutions, interests and ideas and the advocacy coalition framework.

Like any public policy, economic policy can be described through its key constituent stages: defining the problem (the target of government action), public action formulation, decision-making, implementation, and finally evaluation of the actions carried out. This sequence can be found, with variations, in public policy theories since the early works of Lasswell [3] [4] [5]. Thus, economic policies implemented after the international crisis in Brazil will be described in terms of their emergency conditions, public policy paradigm and political actor dynamics interaction.

According to Jobert and Muller [6], the political sociology of public action assumes that public policy analysis must be integrated into a broader conception of state-society relations. Its composition is arranged in three elements: the sector-global relationship, the referential and the actor's interaction dynamics involved in the power relations and regulation of a specific public policy.

The sectorial-global relationship is primarily an attempt to manage the relationship that is established between the sector considered in public policy and the other areas and government and social life. Its logic consists in the constant exercise of adjusting different areas, interests and powers. In the study presented here, the sectorial is the economic policy adopted by the Brazilian government after the economic crisis. Sectorial-global relations happen in multiple arenas. First, to be successful, policy changes needed support and complementarity of the other government areas. Many ministries were involved, for example, in the design and implementation of the PAC-Growth Acceleration Plan, My Home, My Life Program, and other actions that made up the New Economic Matrix policy package.

Subsequently sectorial-global relations express how actors involved in public policy action articulate themselves. This relationship can also reveal the existents conflicts and power disputes inside public institutions. According to Jobert [7] [8], it is a mistake to consider the State as a unified and homogeneous entity and the public administration as a rational executor of governmental decisions. The various parts of government can represent, and often do, distinct, often complementary, and sometimes conflicting social and economic interests. Thus, government functioning and public policies actions fit into a logic of the sectoral-global and dialectical relationship between the demands of legitimacy and regulation.

The second key element is called a referential and covers a set of norms, learning and references that are expressed in a public policy. The referential can also be described as the representation made by the actors involved in this action. This representation is the way in which the various actors and social classes involved understand the origin, the development and the possible unfolding of the problem to be the target of the action of the State and it is also the expression of the perception of the role that must be played by the government in that time. They are norms and references built by the actors involved through their rela- 
tionships, interactions, consensus constructions and decisions. To know how the referential is elaborated is to know how the actors themselves see their respective roles, functions, values and interests. The definition of the referential influences the way in which the relation with the power of the State will be guided and how the actions and decisions of the group of actors will take place.

The referential framework can be divided into three parts: global, sectoral and articulation. The first part is sectorial self-representation which is not always a coherent and rational one. It is the state role and type representations. The sectorial referential is the dominant image of economic, political and social sectors. The last part-the articulation-are the norms that integrate the two levels, the global and the sectorial. It is the way the government responds to the needs and demands coming from economic sectors and from political and social organizations. "The referential of a public policy, understood as the representation of global-sector relations, has the effect of structuring the field of a public policy. It determines the geographical or social extension and hierarchizes its objectives" [6].

The third and final key element is to look for and describe who are the actors who work in the construction of the referential. That is, knowing who the actors are that build the image of the system to be regulated. At this point, the set of actors encompasses the various state actors, local, regional or national and non-state actors, representatives of specific sectors of the economy and society. Another question is how the system will be regulated, from which values, principles and mechanisms? The regulation refers to the norms, procedures and public power actions legitimation. And finally, what is the outcome of these actions in terms of old and news power relations. Constituents actors of public policies relations are marked by acts of cooperation, conflicts and power struggles.

In addition, the functioning and interaction of the key elements must be considered according to the action cycles. Müller [9] and Faure and Müller [10] identify four cycles. They are: the industrial liberal, the welfare state, the state-enterprise and sustainable governance. Cycles are social configuration processes that define the role of state action and public policies for society. Each cycle corresponds to different economic, citizenship and public policy regimes that express the referential in which the State is inserted. The basis of these cycles is the configuration of Western European states. In our case, the cycles are others and refer to other dispositions of the political and economic forces acting in public policies.

An approach complementary to the political sociology of public action (and its three key foundations) is the "three Is" theory: institutions, ideas and interests. According to Palier and Surel [11], public policies analyses must cover the interaction between these three dimensions. Institutions concern to political organizations that shape and condition the actions of social actors. Durkheim [12] defined institutions as being instituted by the collectivity and they impose themselves on us and we support them for the advantages we take by obeying them. 
Having a normative character [13] they create the game rules and create, within the State, a system of (sometimes) contradictories decision-making in their spheres of action. Interests involve the objectives of each social actor in public policy. There is always an arrangement of interests between private and public action spheres. Finally, ideas refer to public policy actors' self-images and representations as well as the values that legitimize the state action itself. The "three Is" are explanatory variables of public policies that, in interacting in different forms, shape and delimit the limits of state action.

One of the most widely used theories to explain changes in public policy is the Advocacy Coalition Framework (ACF). Since its inception in the late 1980s, ACF has been used to describe the most diverse changes in public action. According to Pierce, Peterson, and Hicks [14], this approach contributes to the understanding of the decision-making processes of changes in public policies, from Brazilian environmental legislation [15] to public economic policy, as in the case of Brazilian macroeconomic policy. Advocacy coalition is a specific form of collective action to shape and change public policy even within closed political regimes. Because it is based on the interaction of actors in the political subsystem, it differs from social movements, interest groups, and political parties [16].

To the advocacy coalition framework [17], there are three steps to understanding policy change: the first is its process requires a time perspective of at least a decade. Second, a policy change study should focus on policy subsystems, which are the actor's interactions in a specific area of public policy. And, third that public policies can work as belief systems, which is "[...] as sets of value priorities and causal assumptions about how to realize them" (Idem, 1988, 131). Sabatier and Weible [18] suggested three essential modifications in the advocacy coalition framework: 1) the importance of the context in which coalitions operate, 2) a typology of coalition resources, and 3) new paths to policy change. The context is vital because the ACF was a successful use in understanding pluralist regimes, but it can also explain changes in the institutional context of developing countries. The typology of coalition resources is a complement of the belief system approach. A robust belief system can only engage in policy change if it has the needed resources to act. Finally, the two new paths to policy change analyses by the ACF are 1) internal shocks and 2) negotiated agreements. Initially the ACF focused on external shocks [19] as a needed cause to policy change. However, this focus was not enough to comprehend policy changes originated by internal political demands or changes in the dominant coalition. Furthermore, negotiated agreements can also result in policy change.

The theory helps us to unveil the actions of the Brazilian State during the crisis of 2008 and their consequences. There was a change of referential (or paradigm) in this period: from the macroeconomic tripod to the new economic matrix. In a similar way, state self-image and role have also changed. It is seen and recognized as responsible for minimizing the effects of the crisis and for being the inducer of economic development. The relationship between the state and 
the economic sectors of society has also changed. State and productive sectors began to act as partners in economic development actions. The field of political action in the sector presents norms and acts changes. Regarding the cycles of action, the change that has taken place has given new appearance to old political relations. It is a new version of the old patrimonialism ([20] [21] [22], the so-called "capitalism of ties" [23] [24]).

The decision to change the economic policy occurs initially as a way to mitigate the effects of the international financial crisis. Its results were positive at first but showed signs of exhaustion a few years later. A decade passed before it was possible to understand the limits of change in economic policy. The subsystem that acted to effect this change encompasses sectors of the workers' party that disagreed with the rigidity of the macroeconomic tripod and the left-wing political parties who supported the government. Other essential economic sectors agreed on this policy change, as several sectors of the Brazilian industry, especially the Federation of Industries of the State of São Paulo (FIESP), unions linked to the auto industry and construction industry. Besides, the context of this change was the 2010 election race, which was won by Dilma Rousseff, a candidate supported by then-President Luiz Inacio Lula da Silva.

The 2008 crisis highlighted the absence of instruments that could prevent its effects from spreading, or for many analysts who needed cooperation between countries. According to Stiglitz [25], the G20 has sought to act together to address the problems caused by the American financial system to avoid or continue with the global economy by a coordinated increase in aggregate demand. This proposal does not represent a consensus on policy changes in economic policies. Brazil has opted for this change, deactivating the macroeconomic that have guaranteed price stability since the 1999 crisis and adopting the new macroeconomic matrix.

\section{The Subprime Crisis and the Transition in Brazilian Economic Policy}

The crisis of 2008 was by far the most important crisis experienced by the international system since 1929. In this section will be exposed to its origins and its repercussions that would end up driving changes in the Brazilian economic policy.

\subsection{The 2008 Financial Crisis: Origin and Nature}

The so-called "subprime crisis" brings important changes to world reality sometimes considered enough to anticipate structural changes in the economic system. It has promoted, by its systemic nature, scenarios and answers still circumscribed to the traditional theoretical and political postulates. Thus, the resurgence of renewed nationalisms represented by the rise of Trump, Erdogan, Orban and Duterte, among others, can be considered a response, for example, to the migration process, which, among other things, has increased significantly in response to geographically localized crises, which seem to result largely from the global crisis that began in 2008 . 
While the object of this article is not to analyze the development of world political history from the great crisis of 2008, leaving this issue to more in-depth studies, it is worth trying to understand this crisis ourselves from the economic point of view and how its effects gave rise to policies in this field in different countries in their relationship with the situation, in order to shape the current international reality.

Such a question necessarily refers to the study of the behavior of FDI flows from the crisis. In one globalized economy justified by a liberal conception of international economic relations the crisis would favor the rise of nationalism in the economy and the FDI flows would be reduced. The Brazilian case can be emblematic in this sense.

Thus, the crisis, according to Bresser-Pereira in 2009:

[...] is a deep crisis of confidence stemming from a chain of loans originally based on insolvent borrowers who, by leading economic agents to prefer liquidity and thus liquidating their claims, are leading banks and other financial firms to break even if they are solvent [26].

For the author, this would be a banking crisis, and, moreover, taking place at the center of capitalism.

Corroborating this idea and looking more closely at the crisis, one can see that it did not begin in 2008, but earlier in 2007 with the bankruptcy of the British bank Nothern Rock, a fact not particularly highlighted by the press in general. This bankruptcy, in turn, refers to the US government's real estate policy in the 1990s, which, with the aim of increasing this market, would create the Federal National Mortgage Association, commonly known as Fannie Mae, and the Federal Home Loan Mortgage Corporation, or Freddie Mac, whose functions would be to provide liquidity to the mortgage market by purchasing real estate loans from banks.

Such loans would become assets sold to investors around the world, generating a secondary market quite sought after to negotiate securities guaranteed by the American government. The practice of securitization, fully endorsed by risk agencies, has exponentially increased speculation activities, involving large international financial organizations.

In addition, the US government pressured banks to carry out real estate lending by triggering the Central Bank to inject money into the banking system, a move that would intensify with the tumultuous events of technology companies and the terrorist attacks on the US at the beginning of the 2000s, leading to a fear of recession.

However, with the recovery of the US economy from 2004, this process would cease, causing interest to begin to rise, significantly affecting the real estate market by reducing the demand for real estate and increasing the level of default on bank loans.

Of course, this situation implied an absolute reduction in the revenues of banks that, by borrowing from the international financial system, granted real estate financing that generated mortgages sold to investment banks. With the 
reduction of real estate activity, the latter's demand would fall sharply, generating a serious liquidity problem for banks that would lead them to a halt in their credit activities in 2008. This is what would lead Roque [27] to call it a perfect storm, initially manifested in 2007 by Northern Rock.

The depth and extent of the crisis would extend to the economy, so that the debate on economic ordering from the perspective of the international political economy would be reversed with a new round of discussions on the capacity for self-regulation of markets and the need for corrective state intervention.

According to Bresser-Pereira [26], the crisis in question can be attributed to national financial systems that, deregulated in the 1970s and supported by the emergence of a neoliberal wave, with an ideological character, would allow, as is still observed today, a resistance to government actions by "markets," particularly financial ones.

According to Farh, Prates, Freitas, Cintra [28], the principle of self-regulation can be expressed as follows:

[...] corporate governance and risk management of banks have evolved to such an extent that their decisions can be considered the most appropriate and efficient in order to avoid the occurrence of episodes that could lead to systemic risk. It was he who guided, to a large extent, the changes of the Basle Accords [...] [28].

It is clear from this assertion that the markets, represented by the private agents, of the financial sector in this case, acquire autonomy in relation to the states in this reality.

Corroborating these positions, Ferrari Filho and de Paula [29] affirm that the deregulation of financial markets, generating "volatility of exchange rates and interest rates," has made it difficult for domestic economic policies to be responsible for "balance of payments crises in emerging economies." And it goes without saying that Brazil is in this scenario.

From this, Oreiro and Correa Basilio [30] would ask the question of whether Brazil would be shielded against this crisis. In their perspective, highlighting the point highlighted by the previous authors, they affirm the need to stabilize the exchange rate. And here is a simple question: When elaborating a foreign exchange policy, the Brazilian government would be facing the effects, but in that policy, is a concern implicitly inserted about the structural aspects of the Brazilian economy, such as the necessity of a policy of productive development consonant to the insertion of the Brazilian economy in the productive sector of the international economy?

Thus, the issue leads to studies on the different aspects of the problem and its consequences, such as the resurgence of nationalisms in the international system. But for the purpose of this article, the important thing to note is that the crisis of 2008, having a systemic character, presents a degree of depth and significant gravity. It extends from one sector and one specific location to the economy. And, mainly, it goes from the financial field to the real productive field, implying a recession that has devastated the lives of several nations, causing social 
impacts expressed in the levels of employment and income. It is therefore interesting to observe the responses to the crisis of 2008 by the Brazilian government, seeing the flows of FDI as an important element for reflecting on the possibilities of sustaining a process of development of the country.

\subsection{The Transition of the Macroeconomic Tripod to the New Economic Matrix: The Brazilian Economy in the Period 1999-2018}

In January 1999, following the occurrence of three international financial crises since the beginning of the process of stabilization of the Brazilian economy with the Real Plan, the government promoted the exchange rate regime, from semifixed to floating. With the end of the exchange rate anchor used as one of the main strategies of price stabilization, an inflation targeting regime was implemented. The details of the functioning of the scheme were presented by Bogdanski, Tombini, and Werlang [31]. The target system basically consists of determining inflation targets to be reached by the Central Bank of Brazil with the use of monetary policy.

The inflation targeting regime, implemented months after the adoption of the floating exchange rate regime, was combined with a fiscal policy to generate primary surpluses. Thus, according to Oreiro [32], the macroeconomic policy regime began to be known as the "macroeconomic tripod," based on the combination of the primary surplus with the regime of inflation and floating exchange rate targets.

The aim of the scheme was to ensure price stability combined with the generation of fiscal surpluses to reduce public debt growth. The contractionary fiscal policy, coupled with an anti-inflationary monetary policy and an unfavorable international scenario resulting from the terrorist attacks of 2001, along with a negative supply shock caused by the energy crisis in Brazil between 2001 and 2002, promoted low economic growth in the four-year period from 1999 to 2002 , with an average GDP growth rate of $2.3 \%$ per year.

The year 2002 was also marked by instability in the Brazilian foreign exchange market due to the electoral scenario, with the advance, in the polls, of the candidate Luiz Inácio Lula da Silva of the Workers' Party. Historically, the candidate and the party advocated unorthodox economic policy measures with increased government spending and a renegotiation/suspension of external debt repayment. This led to capital flight and increased country risk, a situation that was reversed after the commitment of the government plan to maintain debt payments and the adoption of a macroeconomic policy of price stability combined with fiscal stability.

In 2003, with the beginning of the new government, the economic policy of generating fiscal surpluses was not only maintained but also amplified by the new economic team. In addition, anti-inflationary measures were adopted, as Giambiagi [33] points out. According to the author, in the field of economic policies of an urgent nature, due to the adverse economic scenario, the following 
stand out: the increase from $3.75 \%$ to $4.25 \%$ of the government's primary surplus target in 2003, the increase of basic interest rate to control inflation caused by the exchange rate devaluation and the negative energy supply shock of the previous year and the announcement of decreasing inflation targets.

In the period 2003-2006, according to Giambiagi [33], there was a significant fiscal improvement in relation to the previous government. Inflation also showed a declining behavior (from $9.3 \%$ in 2003 to $3.14 \%$ in 2006). The "macroeconomic tripod" had been applied systematically in the Brazilian economy. However, according to Oreiro [32], as early as in 2006 this regime underwent transformations, with the change in the accounting of investments of the primary surplus target. Complementary changes occurred in the economic team, with the entry of Minister Guido Mantega in place of Antonio Palocci. Other measures, such as the abandonment of the downward trend in inflation targets and the Brazilian Central Bank's performance in the foreign exchange market to minimize the nominal appreciation of the exchange rate, have made the tripod more flexible and stimulated the economy through incentives on the demand side.

In this context, according to Oreiro [32] the expansion of aggregate demand through the growth of primary government spending coupled with a policy of appreciation of the minimum wage provoked a real appreciation of the exchange rate and deficit in current transactions from 2007. According to the author, appreciation of the exchange rate led to a loss of competitiveness and loss of dynamism in the industrial sector, which was reflected as a threat to the sustainability trajectory of the Brazilian economy.

As a reaction to the effects of the crisis, the government deepened, even more forcefully, the flexibilization of the macroeconomic tripod, as highlighted by Oreiro [32]. According to Jorge and Martins [34], the government postponed the collection of taxes, such as the Tax on Industrialized Products (IPI), the Social Integration Program (PIS), the Contribution for Social Security Financing (Cofins) of income withheld at source and accelerated the return of tax credits to companies. Expenses with the Growth Acceleration Program (PAC) and with social programs were maintained and increased, especially through Treasury loans, public banks (mainly the Banco do Brasil and Caixa Econômica Federal) and the National Bank for Economic and Social Development (BNDES).

Specifically, concerning the BNDES, part of the disbursements was allocated to companies that increased investments abroad. BNDES provides credit lines for the internationalization of companies, with emphasis on Foreign Direct Investment Operations (FDI) and projects or investments abroad. In this way, it is possible to establish a relationship between the bank's financing and the direct investment inflows and outflows.

The historical growth trend of BNDES disbursements showed acceleration as of 2006, when total disbursements were $\mathrm{R} \$ 51.3$ billion. In 2010, disbursements totaled R \$168.4 billion. After a slight decline in 2011 and 2012, the year of 2013 registered a peak of R $\$ 190.4$ billion and, from then on, disbursements began to 
decrease, as shown in the following figure. The subsidized credit through the BNDES was one of the determinants for the expansion of Brazilian investments abroad (Figure 1).

In this context, the "Macroeconomic Tripod," which consisted of the combination of primary surplus with the regime of inflation and floating exchange rate targets, was replaced by the so-called "New Economic Matrix." The term "New Economic Matrix" was cited by the Ministry of Finance for the first time in 2012 and was characterized by the combination of low interest rates with devalued exchange rates and fiscal policy favorable to public investment. Pessoa [36] complements the New Economic Matrix context with the scenario in which the State assumed a more interventionist and protectionist role, not only reducing the real interest rate, but also expanding subsidized credit and devaluing the exchange rate to recover the dynamism and competitiveness of the industrial sector, among other actions.

Some of these actions were adopted immediately after the subprime international financial crisis and unequivocally allowed the Brazilian economy to resist the effects of the crisis. Despite the first drop in GDP in 18 years, since in 2009 the Brazilian economy showed a decrease of $0.2 \%$ in GDP, which had not occurred since 1992, the flexibilization of the macroeconomic tripod allowed the Brazilian economy to present a growth rate of $7.5 \%$ in 2010.

However, the intensification with a consequent perpetuity of the flexibilization of the macroeconomic tripod resulted in low growth in subsequent years. One reason was the loss of credibility of the Central Bank of Brazil, according to Barbosa Filho [37]. According to the author, the change in the conduct of monetary policy raised the cost of fighting inflation by allowing the acceleration of inflation combined with a reduction of credibility by the Central Bank of Brazil. Another factor, cited by Barbosa Filho [37], was the deterioration of public accounts resulting from fiscal stimulus (subsidies and deregulation).

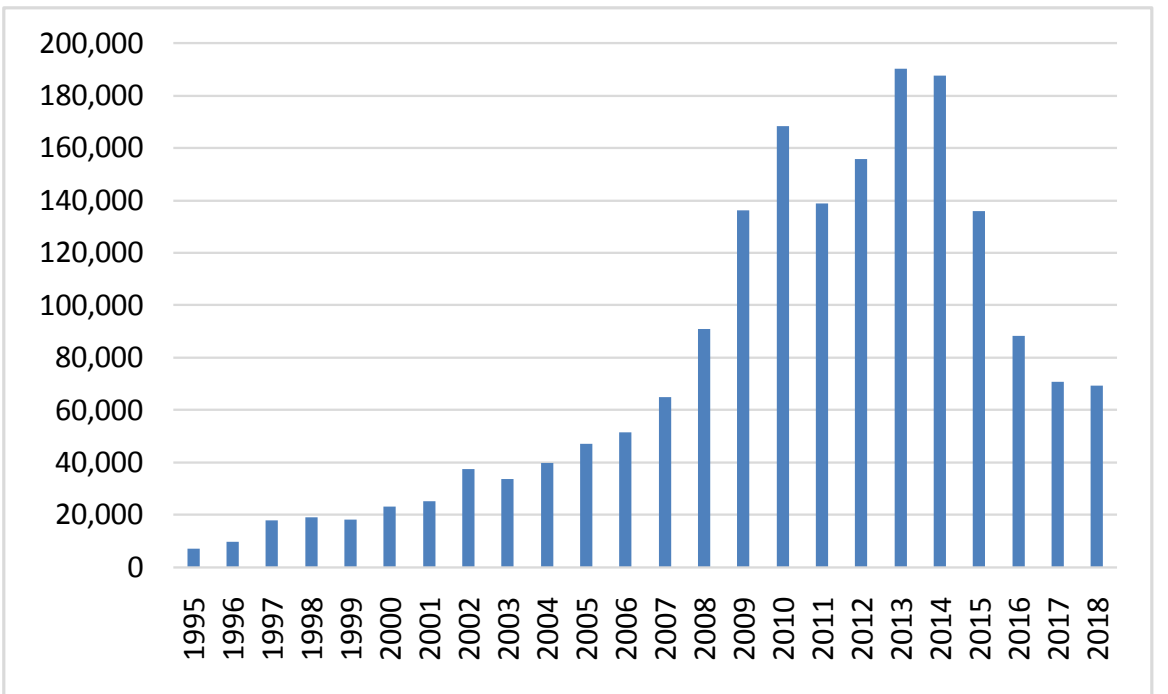

Figure 1. Disbursement of the BNDES system in R \$ million. Source: BNDES [35]. 
Carvalho [38] made numerous criticisms regarding the expansionary fiscal policy of the Dilma government based on tax relief. In fact, the Brazilian companies that received subsidized loans from the BNDES benefited from the favorable condition and extended the internationalization process in the transition period from the Macroeconomic Tripod to the New Economic Matrix. Hence, it was verified that the period of inversion of the upward trajectory of BNDES disbursements coincided with the loss of dynamism of Brazilian investments abroad, as will be seen in the following section.

According to Oreiro [32], the policy of the New Economic Matrix was doomed to failure from the outset, since it was not possible to eliminate the exchange rate appreciation of the economy in a concomitant manner with the permanent reduction of the interest rate level. This was because, with a process of nominal and real devaluation of the exchange rate, an inflationary acceleration would be expected that would require a contractionary monetary policy, interrupting or partially reversing the resumption of the competitiveness of the economy.

The views that point to the inconsistency of the New Economic Matrix are questioned by other authors based on determinants of an internal and external nature that were not the result of macroeconomic policy, that is, of exogenous factors in relation to the new matrix. Borges [39], for example, believes that the low growth of the Brazilian economy in the first government of Dilma Rousseff (2011-2014), which had an average rate of $2.3 \%$, compared to a rate of $4.6 \%$ in the previous four-year period (2007-2010), was also caused by issues such as falling commodity prices in the international market, among other factors. It is worth mentioning that the period 2015-2018 had even worse results, with an average GDP growth rate of $-1.2 \%$. The result is that, according to the Getúlio Vargas Foundation's Economic Cycle Dating Committee, in the period from the second quarter of 2014 to the last quarter of 2016, the country faced the worst recession since the crisis of 1981-1983. In the recent recession, the cumulative fall of $8.2 \%$ in 11 quarters was not greater than that in the debt crisis that Latin America faced in the 1980s, which did not have a significant impact on the attractiveness of the economy for foreign direct investment.

\section{Foreign Investment: Evaluation of Inlet and Output Flows}

This section looks at the movements of FDI inflows and outflows of foreign capital, as well as analyzes these balances based on the Grubel-Lloyd index.

\subsection{FDI in Brazil: An Assessment of Recent Flows}

At the end of the second half of the twentieth century, FDI inflows into Brazil were driven by the growth in demand stimulated by state action [40], a trend that was significant during the Brazilian military regime (1964-1985). This policy allowed the increase of income for the middle class and the increase of financing and loans for consumption. Between 1974 and 1981 the Brazilian government sought to direct these flows through the demand of the state for capital goods. 
Such approach has conditioned the entry of foreign companies into the most dynamic sectors of the Brazilian economy, so that most of the resources went to the manufacturing industry.

The Eighties were marked by a deep economic crisis, accompanied by an expressive drop in FDI inflows, a condition that was only reversed after the Real Plan (1993-1994), when Brazil returned to the international financial system. Another important context on which the interpretation of this capital movement should be based is the intensification of the process of economic globalization, which is materialized, among other events, in the expressive growth of the global flow of FDI, as shown in Figure 2.

It is also worth mentioning the increase in the allocation of part of these capitals to the block of developing countries in this period, which also explains the reversal in the inflow of productive capital in Brazil as shown in Figure 2 and Figure 3, even though the country is among the main hosts of FDI.

Despite this new scenario, Brazil's participation in the overall volume of FDI is increasing, and the country cannot resume the levels of participation in foreign capital flows registered during the second half of the Seventies, a fact that can only be observed from 2010, as shown in Figure 3.

However, the growth rate of FDI in Brazil is quite significant, from US $\$ 2.15$ billion in 1995 to US $\$ 96.15$ billion in 2011 (current values).

As regards the total flow between the years 2000 and 2016, Brazil was the sixth largest welcoming FDI, with an average participation in the period of $3.4 \%$. The country that received most FDI was the United States, which received $16.9 \%$ of the global flow, followed by China, whose share in the total flow was 7.1\% [2].

If we analyze only the years that followed the crisis of 2008, Brazil maintained the growth trend of FDI inflows in 2008, which was broken in 2009, but grew

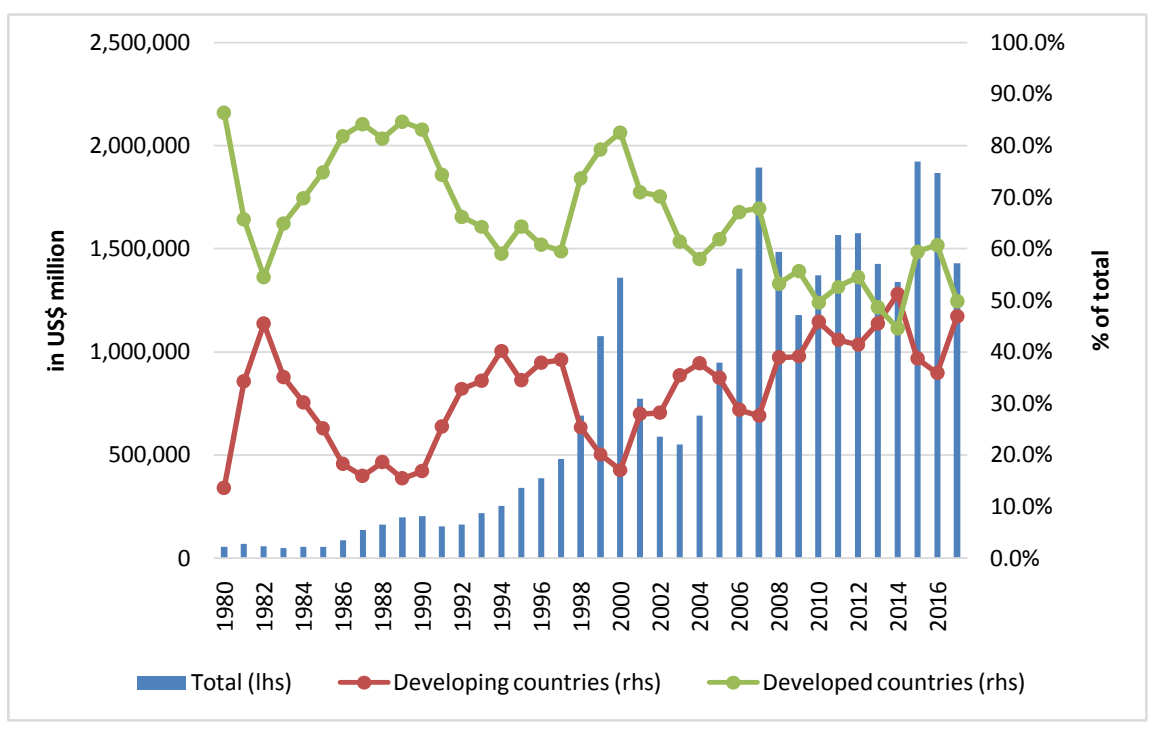

Figure 2. Global FDI flow (inputs) 1980/2017 in US \$ million (current values) and percentage share of developed and developing countries in the global flow (in \%). Source: Unctad Stat [2]. Note: lhs = left scale; rhs = right scale. 


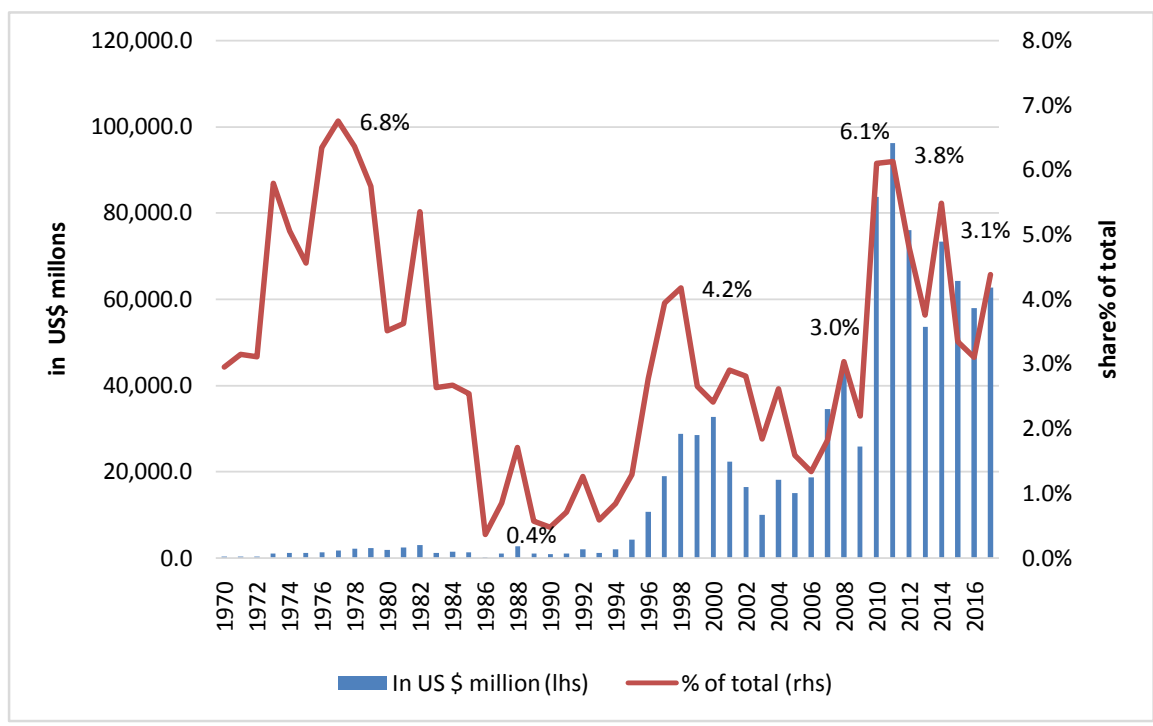

Figure 3. FDI inflow in Brazil 1970/2017 in US \$ million (current values) and part. \% in overall flow. Source: Unctad Stat [2]. Note: lhs = left scale; rhs = right scale.

significantly in the years 2010 and 2011, when they were the largest inflows of capital throughout the series surveyed, as shown in Figure 3. It is worth noting that the decline in FDI inflows in Brazil in 2009 reflected the trend of global flows, as shown in Figure 2.

This new context of resumption of FDI inflows in Brazil obviously affects the productive structure of the country in terms of the participation of foreign companies in income generation, a fact that is evidenced by the ratio of FDI stock to GDP, which ranged from $9 \%$ in 1990 to 38\% in 2017, as shown in Figure 4.

Although this indicator is important for assessing the degree of internationalization of domestic production, it should be noted that the ratio (FDI stock/GDP) does not represent how much of the domestic production is performed by foreign companies. However, reason is an indicator commonly used to assess the growth of the importance of these capitals to an economy.

As to the destination sectors of these FDI, up to 1985 , about $75 \%$ of the capital received by Brazil was destined for the manufacturing industry, while utilities accounted for only $0.2 \%$ of total FDI (BCB).

Starting in the 1990s, with the return of investments to the country, a new reality began to emerge in relation to the sectors, with industry losing space to the services sector, emphasizing that during the two administrations Fernando Henrique Cardoso was part of these capitals, aimed at the acquisition of privatized companies of the sector of public utility services.

In general, Laplane et al. [41] believe that the main determining factors for the attraction of these capitals to Brazil from the 1990s were access to the Brazilian domestic market, which is large and dynamic, deregulation of the national economy, the commercial opening and privatizations. Besides these factors, Gonçalves [42] also highlights the importance of the economic stability achieved 


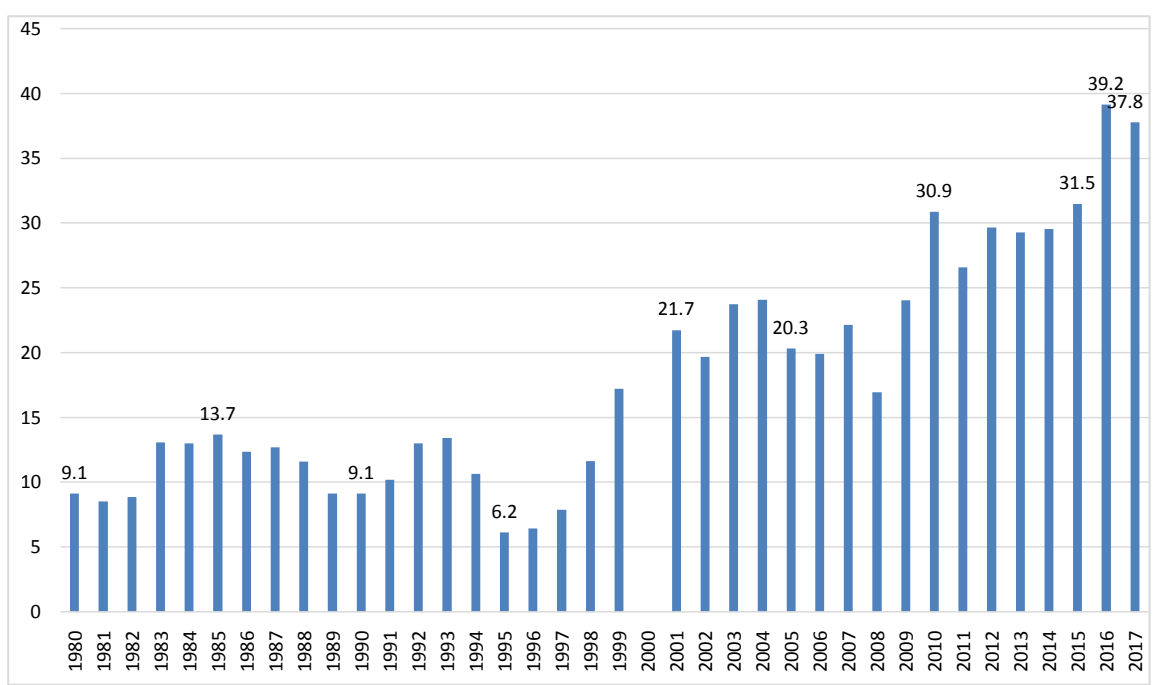

Figure 4. Stock of FDI/GDP Brazil 1980/2016 (in \%). Source: Unctad Stat [2].

by the country from the Real Plan, in addition to the potential represented by MERCOSUR.

Figure 5 shows the sectoral distributions of accumulated FDI flows by period, divided into three groups (Agriculture, Cattle Raising, and Mining, Industry and Services), confirming the assertion of investment in the target sectors of foreign productive capital, with the fall in the share of the industrial sector and the rise of the services sector.

\subsection{Investment (Brazilian) Direct Abroad: An Evaluation of Recent Flows}

When analyzing the flows of outflow of direct investment in the country it is found that developed countries still predominate, despite the recent growth of developing countries share in the global flow.

On average, the share of developed countries as of 2000 was $88.7 \%$ of the global flow. Although the share of capital from developing countries is modest, there is a trend of growth of these flows from 2009. Also noteworthy is the fact that in the years of the crisis, the relative participation of developed countries reached $93.7 \%$ in 2008 and $94.7 \%$ in 2009 . Only now have developing countries resumed their more active participation in the global flow. For more details see Figure 6.

As part of the block of developing countries, Brazil is not among the main "exporters" of productive capital, unlike what happens when FDI inflows are analyzed, in which the country was the sixth largest. When analyzing the behavior of Brazilian companies abroad, it is verified that the country is in 34th place in the ranking with a participation of only $0.4 \%$, if the accumulated flow between the years 2000 and 2016 is analyzed. The United States is the main "exporter" of direct investment, concentrating $20 \%$ of the global flow, followed by Japan, which has a participation of $6.5 \%$ in the total flow [2]. 


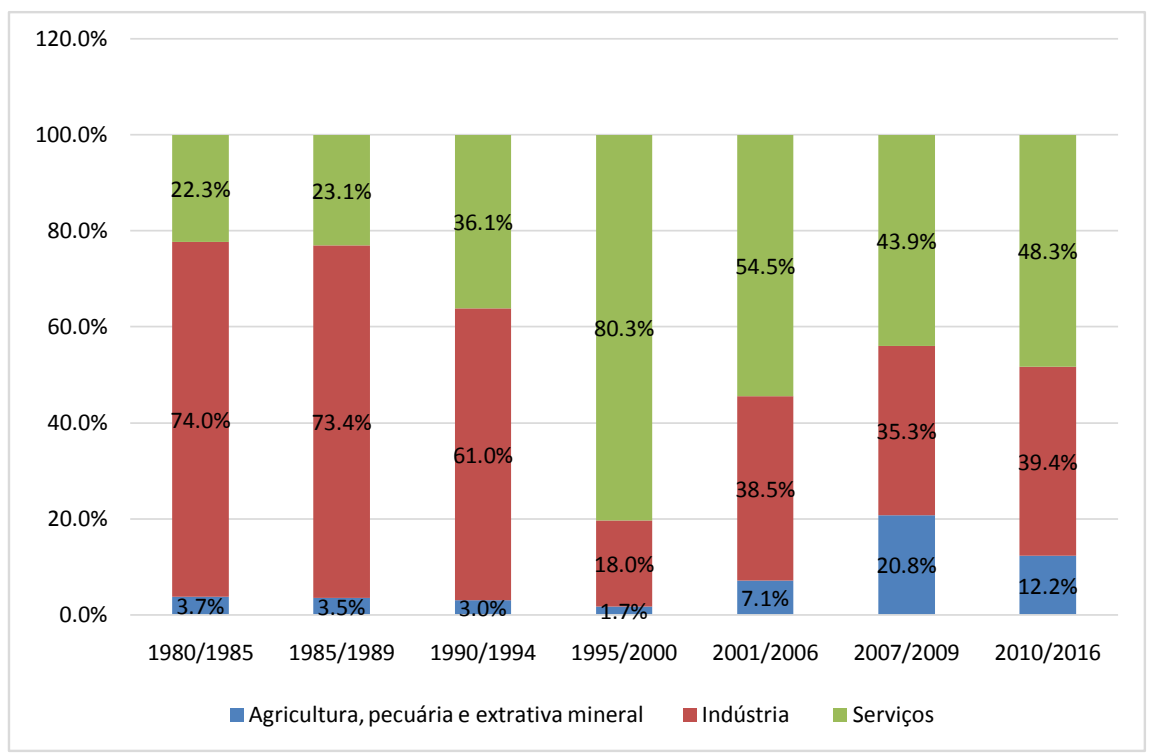

Figure 5. Sector distribution of FDI inflows (share \% of total). Source: Central Bank of Brazil (historical series of FDI) [43] [44].

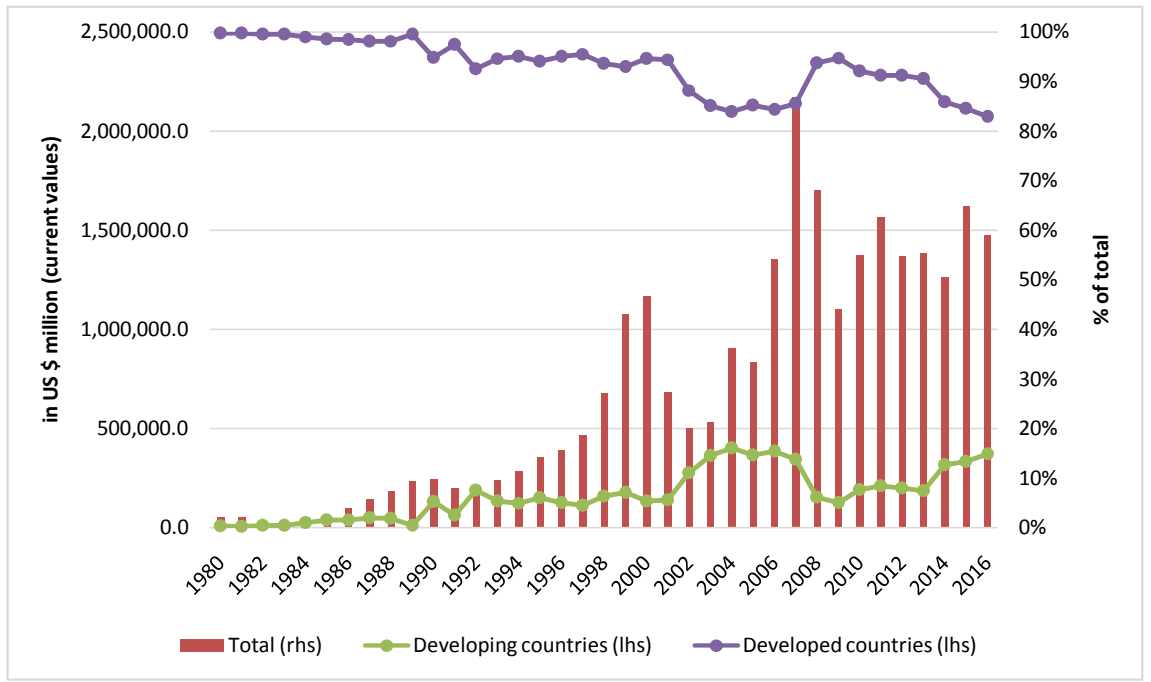

Figure 6. Global flows of FDI (outflows) 1980/2017 in US \$ million (current values) and percentage share of developed and developing countries in the global flow (in\%). Source: Unctad Stat [2]. Note: lhs = left scale; rhs = right scale.

Analyzing the Brazilian direct investment abroad further, it can be seen that the national participation is very modest in the global flow, except for the years 2006, 2008 and 2010, when the Brazilian flow represented 2.1\%, 1.2\% and 1.6\%, respectively, which are specific situations for these years, since in the others, levels similar to the average calculated for the period 2000/2016 were recorded. For more details see Figure 7.

In sectoral terms, there is a higher incidence of "export" of capital linked to service activities, which on average represented $56.7 \%$ of the total flow between the years 2006 and 2016. The industry was present in $31.8 \%$ (on average) of the 


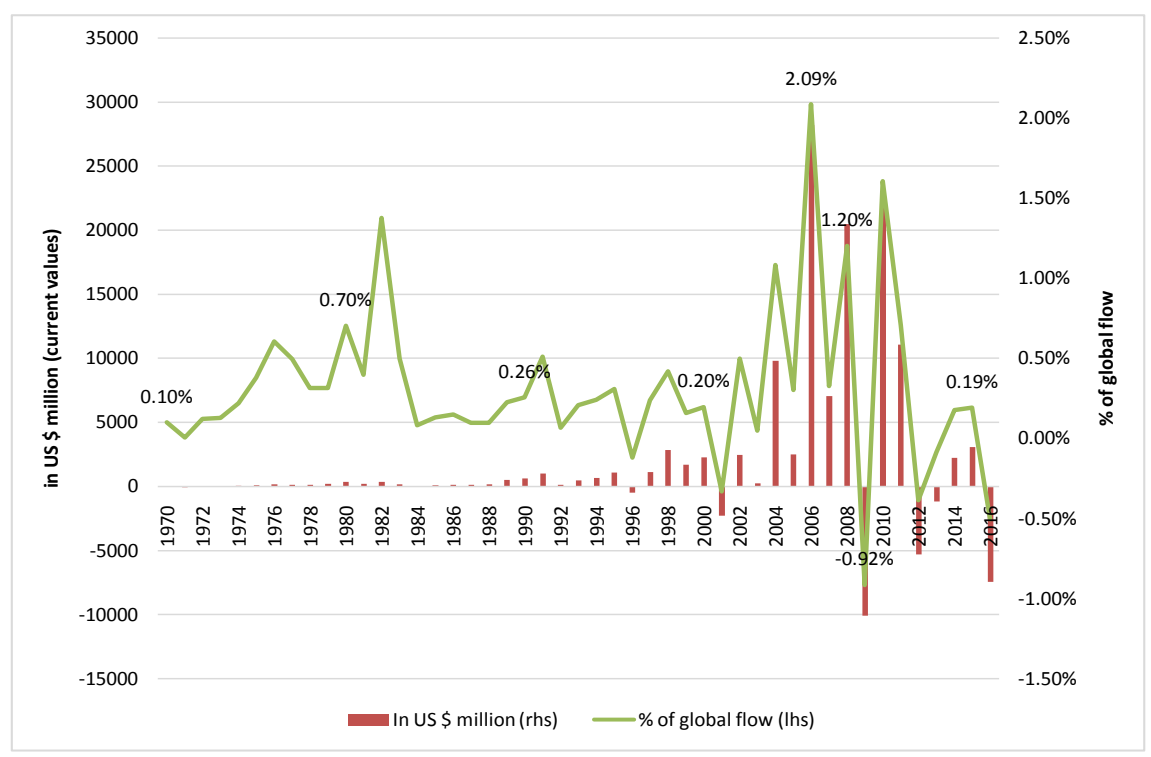

Figure 7. Brazil 1980/2017 in US \$ million (current values) and percentage participation of developed and developing countries in the global flow (in \%). Source: Unctad Stat [2]. Note: lhs = left scale; rhs = right scale.

exported investments in the same period, while the mineral extractive sector had an average participation in this same total flow of $8.7 \%$. The agricultural sector had a very modest participation, which did not reach $1 \%$ in the average of the period. For more details see Figure 8.

Next, the indicators of entry and exit of FDI will be confronted with the objective of analyzing the Brazilian reality based on the Grubel-Lloyd index.

\subsection{The Grubel-Lloyd Index}

With the objective of broadening the evaluation of the internationalization process, through the inflows and outflows of FDI, this article applies the economic indicator called the Grubel-Lloyd index [45].

The index of Grubel and Lloyd (GL index) became popular in the late 1970s, with research related to the determinants of the pattern of trade between countries after numerous attempts to explain the determinants of international trade from a theoretical and empirical point of view, from the Ricardian model to the modern theories of international trade that consider markets of imperfect competition and the occurrence of economies of scale as an important source for commerce.

The present analysis is based on Grubel [46], who made an adaptation in the GL index related to the trade flows for the flows of foreign direct investment. For the purposes of this study, the GL index for foreign direct investment (FDI) is calculated for Brazil and for the block of developed countries according to the following expression:

$$
G L_{F D I}=\frac{\left(F D I_{\text {out }}+F D I_{\text {in }}\right)-\left|F D I_{\text {out }}-F D I_{\text {in }}\right|}{\left(F D I_{\text {out }}+F D I_{\text {in }}\right)}
$$




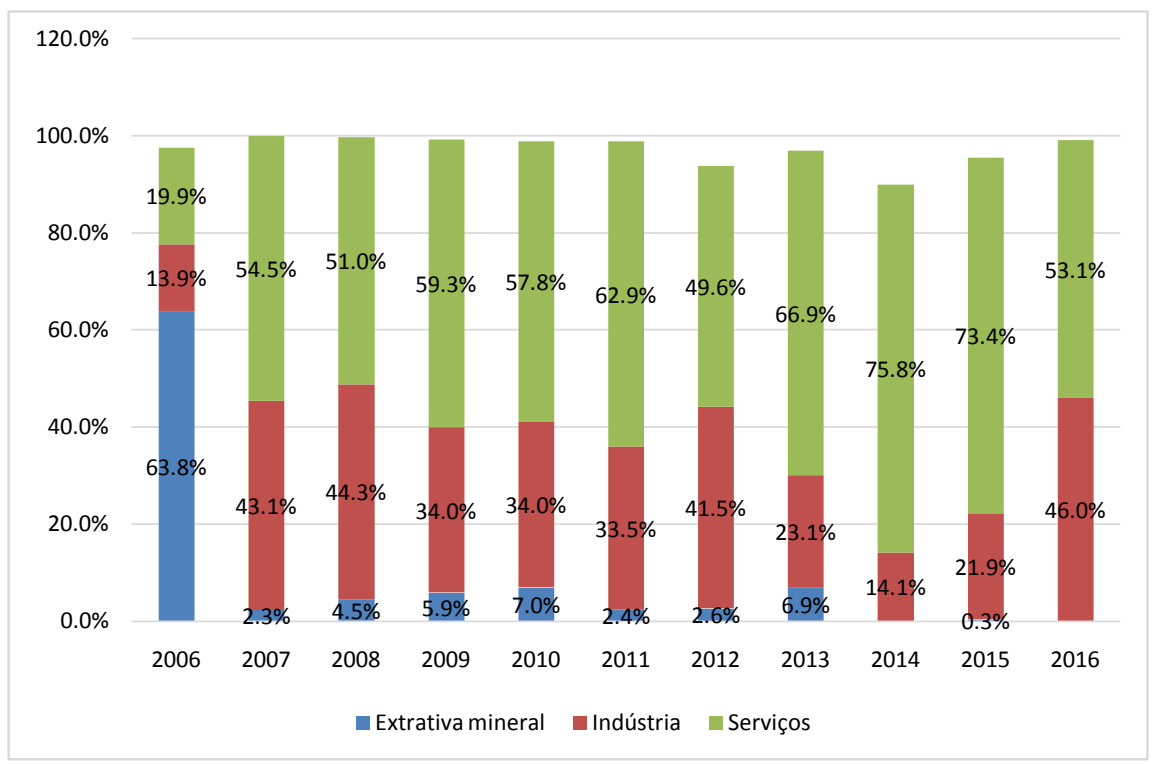

Figure 8. Sector distribution of FDI outflows' (\% of total). Source: Central Bank of Brazil (historical series of FDI) [43] [44].

where:

$G L_{F D I}=$ Grubel-Lloyd Direct Investment Index.

$F D I_{\text {out }}=$ Brazilian direct investment abroad.

$F D I_{\text {in }}=$ Foreign direct investment in Brazil.

According to the adapted GL index, it is possible to calculate the inflows and outflows of FDI and to understand the dynamics of the flows for a given economy. The result of the GLIED equation will always lie in the interval $[0,1]$. When the flow occurs only in one direction, or predominantly in one direction, the calculation result will approach zero. On the other hand, the closer the input and output values, the closer to one will the result of the equation be, emphasizing a process of economic internationalization that considers the degree of financial openness from the perspectives of entry and exit of productive capital.

Results and Discussion: Analysis of the Inflows and Outflows of FDI from the Adapted Grubel-Lloyd Index

As shown in Figure 8, the GL index for developed countries shows relative stability when compared to Brazil, as well as a rather high result, which means a regular pattern when input and output flows are evaluated concomitantly.

As for Brazil, as was initially analyzed, it had significant inflows of FDI in periods other than the national economy. The period between 1997 and 2001 was marked by the process of privatization of state-owned enterprises, while in the second period, between 2003 and 2008, there was a strong increase in commodity prices in the international market and economic growth concomitant with price stability. After the fall in inflows during the international crisis of 2008, the 2011-2012 biennium resumed the growth trajectory, providing the largest inflows registered.

About the investment of Brazilian residents abroad $\left(\mathrm{FDI}_{\text {out }}\right)$, an upward trend 
can be seen from 2003, which was also interrupted by the 2008 crisis. We also note an oscillatory behavior of Brazilian investment abroad (Figure 9).

This erratic behavior of the GL index for Brazil differs from that of the group of developed countries. In addition, the index is well below that calculated for the block in question. For the period 1995/2016 the average GLIED for developed countries was 0.87 , while the GLIED for Brazil was 0.26 (Table 1).

As for the erratic movement of the indicator for Brazil, this assertion is confirmed considering that the coefficient of variation (in relation to the average) is $76 \%$, while the same descriptive statistic for the block of developed countries is only $8.5 \%$, as shown in the table above.

In general terms, it can be observed that in the post-crisis period, Brazil began to register negative results in the Brazilian remittance account abroad and an oscillating movement when FDI inflows are considered, which does not even allow for the calculation of the GL index in a few years.

These results show that there was a reduction in FDI inflows, but volumes remained significant, as shown in Figure 3. However, Brazilian companies did not continue their investments abroad, and even repatriated part of the funds remitted, as shown in Figure 7. However, the change in the strategy of internationalization of Brazilian companies as of 2009 does not exactly follow the trend of BNDES disbursements, which, reflecting the maintenance of the adopted economic policy, only started to register a decrease from the year 2015, as shown in Figure 1.

The GL index describes changes in the process of internationalization of the Brazilian economy as a result of the global crisis. There is a discrepancy between the intended objective of the public policies and the observed results. The new economic matrix was intended to stimulate the continuity of the process of

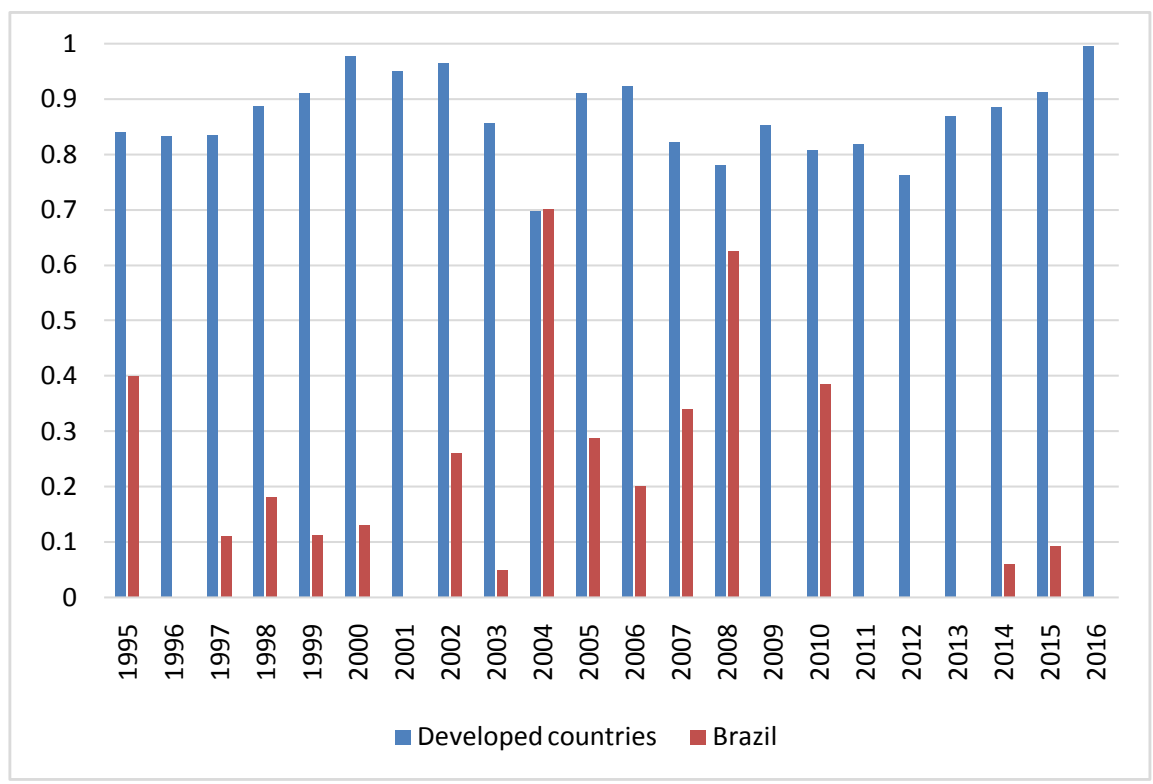

Figure 9. Grubel-Lloyd index developed countries and Brazil 1995/2012. Source: Prepared by the authors based on Unctad Stat [2]. 
Table 1. Mean, standard deviation and coefficient of $G L_{F D I} 1995 / 2016$.

\begin{tabular}{cccc}
\hline Countries & Average & Standard deviation & Coefficient of variation \\
\hline Developed countries & 0.87 & 0.07 & $8.5 \%$ \\
Brazil & 0.26 & 0.20 & $76.0 \%$ \\
\hline
\end{tabular}

Source: Prepared by the authors based on Unctad Stat [2].

internationalization of Brazilian companies, essentially by the BNDES' offer of resources. This continuity was not observed, which indicates a mismatch between the action of the government and the behavior of the economic agents. The passage of public policies based on the framework of the macroeconomic tripod for those based on the new economic matrix expresses a change in the very role the state should play in economic development. The success of this action depended on the fulfillment of the expectations that underpinned this public policy. The failure of these actions would point to a lack of acumen on the part of the policymakers or an inconsistency in the response of the economic agents.

\section{Conclusions and Implications}

The article's objective was to present public economic policy changes in Brazil stimulated by the economic crisis of 2008 and its possible effects on the flows of foreign direct investment. Two public policy approaches explaining the changes have been presented: the political sociology of public action and the theory of the "three Is." The shift from the macroeconomic tripod to the new economic matrix is seen as a change in the referential; that is, it is a change in the foundations, legitimation and actions that make up public policies. Thus, it also changes the social representation of state action obligations and scopes. Therefore, stronger state intervention in public policies was legitimized, because it began to be seen as the main inducer of economic development. In fact, these changes retook the references of the developmental approaches that marked the economic policies in Latin America countries in the twenty century second half. Thus, the proposition about the state's cycles of action (liberal, social welfare, regulatory and governance) cannot be used to explain the Brazilian State's pathways that constantly resume and resign models of action where he is the main actor. Actors dynamics interaction dynamics in the case studied was marked by questions of mismatch between expectations and actions between government and economic agents. Through the "Three Is" approach (institutions, ideas and interests), it was possible to realize that referential chances gave new directions of the governmental actions as well as to the ideas that legitimize them. The interests of the actors involved marked the mismatches described in the text.

The origins of the 2008 international crisis were described, as they were assimilated in Brazil, justifying public policy changes expressed in the passage from the macroeconomic tripod to the new economic matrix. Data were presented that show the historical variations of the flows of direct investment and its com- 
position. The Grubel-Lloyd index was adapted to demonstrate the dynamics of investment flows and their possible relations with changes in public policies.

In short, after the economic crisis of 2008, foreign direct investment flows were expected to fall, both in and out. Inbound flows declined in 2009 followed by a significant upward trend from 2010. As for outflows, there was also a sharp decline in 2009, followed by significant growth in biennium 2010-2011 and a downward movement from then on. This may be related to the scenario of low-interest rates present in the new economic matrix, combined with an increase in BNDES disbursements, which, as noted, has a specific credit line for the internationalization of Brazilian companies. Thus, the change in economic policy mitigated a probable drop in Brazilian investment abroad by providing loans on more favorable terms and interest rates, as well as the inflow of foreign investments in the country.

One of the explanations for the recent economic and political crisis, which began in 2015, would be a consequence of the change in the macroeconomic policy implemented in response to the 2008 crisis. In this sense, the present paper reinforces the importance of studying trends in foreign investment direct flows in Brazil.

\section{Conflicts of Interest}

The authors declare no conflicts of interest regarding the publication of this paper.

\section{References}

[1] Grubel, H.G. and Lloyd, P.J. (2000) Intra-Industry Trade: The Theory and Measurement of International Trade in Differentiated Products. Halsted Press, New York.

[2] UNCTAD (2019) Foreign Direct Investment: Inward and Outward Flows and Stock, Annual-United Nations Conference on Trade and Development. https://unctadstat.unctad.org/wds/TableViewer/tableView.aspx?ReportId $=96740$

[3] Lasswell, H. (1951) The Policy Sciences: Recent Developments in Scope and Method. Stanford University Press, Redwood City, 3-15.

[4] Lasswell, H. (1956) The Decision Processes. Seven Categories of Functional Analysis. University of Maryland Press, College Park.

[5] Lasswell, H. (1970) The Emerging Conception of the Policy Sciences. Policy Sciences, 1, 3-14. https://doi.org/10.1007/BF00145189

[6] Jobert, B. and Muller, P. (1987) L'état en action: Politiques publiques et corporatismes. Presses Universitaires de France, Paris.

[7] Jobert, B. (1985) L'état en action. L'apport des politiques publiques. Revue Française de Science Politique, 35, 654-682. https://doi.org/10.3406/rfsp.1985.394207

[8] Jobert, B. (2004) Une approche dialectique des politiques publiques. Journal Pôle Sud, 2, 43-54. https://doi.org/10.3406/pole.2004.1201

[9] Muller, P. (2015) Mise en perspective. Une théorie des cycles d'action publique pour penser le changement systémique. In: Boussaguet, L., Jacquot, S., Ravinet, P. and Muller, P., Eds., Une French touch dans Panalyse des politiques publiques? Les 
Presses de Sciences Po, Paris, 405-435.

[10] Faure, A. and Müller, P. (2013) Cycles, réseaux, récits: Questions de recherché sur l'action publique locale-globale. Halshs, Montpellier.

[11] Palier, R.B. and Surel, Y. (2005) Les “trois is" et l'analyse de l'état en action. Revue Française de Science Politique, 55, 7-32. https://doi.org/10.3917/rfsp.551.0007

[12] Durkheim, E. (1919) Les règles de la méthode sociologique. Librairie Félix Alcan, Paris.

[13] Rizza, R. (2008) Néo-institutionnalisme sociologique et nouvelle sociologie économique: Quelles relations? Revue Interventions Économiques Papers in Political Economy, 38, 1-21. https://doi.org/10.4000/interventionseconomiques.292

[14] Pierce, J.J., Peterson, H.L. and Hicks, K.C. (2017) Policy Change: An Advocacy Coalition Framework Perspective. Policy Studies Journal. https://doi.org/10.1111/psj.12223

[15] Alves de Medeiros, E. and Gomes, R.C. (2019) Coalizões de advocacia e estratégias de negociação na revisão do Código Florestal. Revista de Administração Pública, 53, 1-22. https://doi.org/10.1590/0034-7612173987

[16] Weible, C.M., Ingold, K., Nohrstedt, D., Henry, A.D. and Jenkins-Smith, H. (2019) Sharpening Advocacy Coalitions. Policy Studies Journal.

https://doi.org/10.1111/psj.12360

[17] Sabatier, P.A. (1988) An Advocacy Coalition Framework of Policy Change and the Role of Policy-Oriented Learning Therein. Policy Sciences, 21, 129-168. https://doi.org/10.1007/BF00136406

[18] Sabatier, P.A. and Weible, C.M. (2007) The Advocacy Coalition Framework: Innovations and Clarifications. In: Sabatier, P.A., Ed., Theories of the Policy Process, Westview Press, Boulder, 189-220.

[19] Sabatier, P.A. and Jenkins-Smith, H.C. (1993) Policy Change and Learning: An Advocacy Coalition Approach. Westview Press, Boulder.

[20] Campelo, R.G.O. (2003) Patrimonialismo em Faoro e Weber e a sociologia brasileira. Revista Dados, 46, 153-193. https://doi.org/10.1590/S0011-52582003000100005

[21] Faoro, R. (2005) Os donos do Poder. Formação do patronato político brasileiro. Editora Globo, Rio de Janeiro.

[22] Werneck Viana, L. (1999) Weber e a interpretação do Brasil. Revista Novos Estudos, 53, 33-47.

[23] Lazzarini, S. (2011) Capitalismo de laços: Os donos do Brasil e suas conexões. Elsevier, Rio de Janeiro.

[24] Musacchio, A. and Lazzarini, S.G. (2014) Reinventando o capitalismo de estado. O levistã nos negócios: Brasil e outros países. Editora Portfolio Penguin, São Paulo. https://doi.org/10.4159/harvard.9780674419582

[25] Stiglitz, J.E. (2019) Lessons from the Financial Crisis and Their Implications for Global Economic Policy. Columbia University Libraries. https://academiccommons.columbia.edu/doi/10.7916/d8-1b0v-m790

[26] Bresser-Pereira, L.C. (2009) Crise e recuperação da confiança. Revista de Economia Política, 29, 113-149. https://doi.org/10.1590/S0101-31572009000100008

[27] Roque, L. (2019) Como ocorreu a crise financeira americana? https://mises.org.br/Article.aspx?id=1696

[28] Fahr, M., Magalhães Prates, D., Penido de Freitas, M.C., Macedo, C. and Marcos, A. (2009) A crise e os desafios para a nova arquitetura financeira internacional. Revista 
de Economia Política, 291, 113-149.

[29] Ferrari Filho, F. and de Paula, L.F. (2009) A crise das finanças desregulamentadas: O que fazer? Revista de Economia Política, 29, 113-149.

[30] Oreiro, J.L. and Correa Basilio, F.A. (2009) A crise financeira brasileira: Uma análise a partir do conceito de fragilidade financeira à la Minsky. Revista de Economia Política, 29, 146-148.

[31] Bogdanski, J., Tombini, A.A. and Werlang, S.R.C. (2000) Implementing Inflation Targeting in Brazil. Working Papers Series 1, Central Bank of Brazil, Research Department, Brasília. https://doi.org/10.2139/ssrn.247507

[32] Oreiro, J.L. (2015) Do tripé macroeconômico ao fracasso da nova matriz: A evolução do regime de política macroeconômica no brasil (1999-2014). Revista Politika, Rio de Janeiro, 16-33.

[33] Giambiagi, F. (2009) A política fiscal do governo Lula em perspectiva histórica: Qual é o limite para o aumento do gasto público? Planejamento e Políticas Públicas, n. 27.

[34] Jorge, C.T. and Martins, N.M. (2013) Política fiscal e a desaceleração da economia brasileira no governo Dilma (2010-2012) Associação keynesiana brasileira. Dossiê da Crise IV: A Economia Brasileira na Encruzilhada.

[35] BNDES (2019) Evolução dos Desembolsos-Banco Nacional de Desenvolvimento Econômico e Social.

https://www.bndes.gov.br/wps/portal/site/home/transparencia/estatisticas-desempe nho/desembolsos

[36] Pessoa, S.A. (2013) Ascensão e queda da nova matriz econômica. Revista Conjuntura Econômica, 67, 10-11.

[37] Barbosa Filho, F.H. (2017) A crise econômica de 2014/2017. Estudos Avançados, 31, 51-60. https://doi.org/10.1590/s0103-40142017.31890006

[38] Carvalho, L. (2018) Valsa brasileira: Do boom ao caos econômico. Editora Todavia SA.

[39] Borges, B. (2017) Impacto dos erros (reais) da Nova Matriz tem sido muito exagerado, Blog do Ibre, 08 de setembro de 2017.

http://blogdoibre.fgv.br/posts/impacto-dos-erros-reais-da-nova-matriz-tem-sido-m uito-exagerado

[40] Nonnenberg, M. (2003) Determinantes dos investimentosexternos e impactos dasempresas multinacionaisno Brasil-as décadasde 1970 e 1990. Texto para Discussão N. 969 do IPEA.

[41] Laplane, M., Sarti, F., Hiratuka, C. and Sabbatini, R. (2000) Internacionalização e vulnerabilidade externa. In: LACERDA, A. C. (Org) Desnacionalização: mitos, riscos e desafios. São Paulo: Editora Contexto.

[42] Gonçalves, R. (1999) Globalização e Desnacionalização. Paz e Terra, Rio de Janeiro.

[43] Central Bank of Brazil. Investimento Estrangeiro Direto.

https://www.bcb.gov.br/acessoinformacao/legado?url=https:\%2F\%2Fwww.bcb.gov. br\%2Frex $\% 2$ Fied $\% 2$ Fport\%2Fingressos $\% 2$ Fhtms\%2Findex3.asp $\% 3$ Fidpai\%3DINV $\underline{\mathrm{ED}}$

[44] Central Bank of Brazil. Investimentos diretos no exterior. https://www.bcb.gov.br/acessoinformacao/legado?url=https:\%2F\%2Fwww.bcb.gov. br\%2Fhtms\%2FInfecon\%2FSeriehistBalanco.asp\%3Fidpai\%3Dseriespex

[45] Alves de Moura Jr., A., Racy, J.C. and Vartanian, P.R. (2018) Análise setorial do processo de internacionalização de empresas brasileiras a partir dos estoques de en- 
trada e saída de investimento direto no período 2000-2014. In: Kon, A. and Borelli, E., Eds., Economia brasileira em debate subsídios ao desenvolvimento, Editora Edgard Blücher Ltda, São Paulo, 91-114. https://doi.org/10.5151/9788580393330-05

[46] Grubel, H. (2002) Intra-Industry Trade in Assets. In: Lee, H.O. and Lloyd, P.J., Eds., Frontiers of Research in Intra-Industry Trade, Palgrave Macmillan, New York, 273-290. https://doi.org/10.1057/9780230285989 14 